\title{
Evaluation of Implementation Within Occupational Health and Safety Management System Based on Indonesia Government Regulation Number 50 of 2012 and ISO 45001:2018 (Case Study: Company
} $\mathrm{X})$

\author{
$1^{\text {st }}$ R.N Asih \\ Post Graduate Student, Department of \\ Civil \\ Engineering, Faculty of Engineering \\ Universitas Indonesia \\ Depok, Indonesia \\ rayinuurasih@gmail.com
}

\author{
$* 2^{\text {nd }} Y$. Latief \\ Post Graduate Student, Department of \\ Engineering, Faculty of Engineering \\ Universitas Indonesia \\ Depok, Indonesia \\ yusuflatief73@gmail.com
}

\begin{abstract}
The development of high rise building in the territory of Indonesia is increasingly growing. The more building construction projects that are running, the higher the number of work accidents that will occur. Therefore, all construction companies must implement a Workforce Safety and Health System which is an important aspect in a project which means to protect workers from the risk of accidents. Company $X$ operates by prioritizing safety and quality (safety \& quality). We maintain our commitment to prioritizing safety and health in the workplace. The Company $X$ synergizes with systems (technology) and people (employees, partners, and other stakeholders) to successfully implement a superior occupational safety and health management system. The implementation and development of OHS Management Systems and the environment in the Company are implemented in accordance with OHS Management Systems standards based on ISO 45001: 2018 and environmental management systems based on ISO 14001: 2015 [1]. With the safety and health management system that has been owned by Company $X$, the authors are interested in evaluating the the OHS Management System.
\end{abstract}

Keywords-Occupational Health and Safety Management System, PP 50 Tahun 2012, ISO 45001:2018

\section{INTRODUCTION}

This study was carried out qualitatively and constructively, evaluating the level of compliance with the OHS Management System and providing recommendations and follow-up for the development of the OHS Management System at Company X. As for the object of research as an independent variable or independent variable is a process component of OHS Management System, while the dependent variable in this study is safety performance process and its compliance based on Indonesia Government Regulation Number 50 of 2012 and ISO 45001: 2018 at Company $\mathrm{X}$ which is currently underway. Based on the object of the research, this study will analyze the compliance of OHS Management Systems to Indonesia Government Regulation Number 50 of 2012 and ISO 45001: 2018 which affect the Safety Performance in the Company X.

\section{LITERATURE REVIEW}

\section{A. Safety in Construction Project}

Construction is heavy work which involves many elements. Not only humans as workers, but also other supporting elements. From the use of heavy equipment to the involvement of large amounts of material. This causes the construction world to have a higher risk of work accidents compared to other types of work. That is why all parties must understand the importance of applying safety to construction projects. The following is an overview of the elements involved in a construction project:

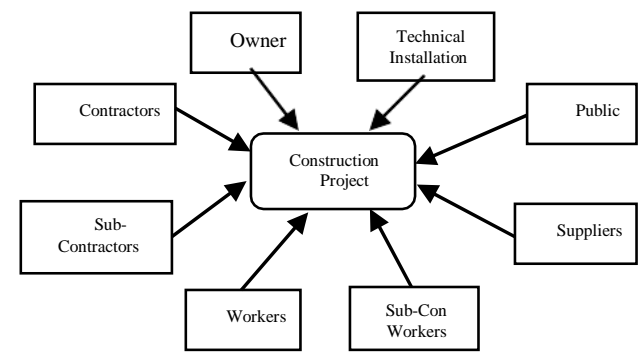

Fig. 1. Elements in the Project

B. Components of OHS Management System based on Indonesia Government Regulation Number 50 of 2012 [2]

\section{1) Safety Policy}

Determination of safety policies is explained in Clauses 7 and 8. In preparing safety policies, employers must at least carry out an initial review of safety conditions, pay attention to continuous improvement in safety management 
performance, and pay attention to input from workers / labor and / or trade unions / unions labor.

\section{2) Safety Planning}

Safety Planning is explained in Clause 9. OHS Planning is carried out to produce safety plans that refer to the safety policies set by the Company.

\section{3) Implementation of Safety Plan}

The implementation of the Safety plan is explained in Clauses 10 to 13 . The implementation of the Safety plan is supported by human resources in the field of Safety, infrastructure and facilities.

4) Monitoring and Evaluation Of safety Performance safety performance monitoring and evaluation is explained in Clause 14

Safety performance monitoring and evaluation is carried out through inspection, testing, measurement, and safety internal audits conducted by competent human resources. The results of monitoring and evaluating safety performance are reported to employers and used to take corrective actions.

5) Reviewing and Improving Safety Performance

The review and improvement of Occupational Safety and Health Management performance is explained in Clause 15. To guarantee the suitability and effectiveness of the implementation of Occupational Safety and Health Management, employers must conduct a review. Reviews are carried out on policies, planning, implementing, monitoring and evaluating.

\section{Components of OHS Management System according to ISO 45001: 2018[3]}

\section{1) Context of Organisation}

Based on the organizational context and identification of interested parties, the scope of the Occupational Safety and Health Management System can be determined. The scope of the Occupational Safety and Health Management System includes products or service activities that can be controlled or influenced by the organization. Furthermore, the Occupational Safety and Health Management System is developed in accordance with other requirements in ISO 45001: 2018.

\section{2) Leadership and Worker Participation}

ISO 45001 encourages top management to be actively involved and responsible for the effectiveness of the OHS management system. That involvement can be done by setting policies, goals, and ensuring effective communication between interested parties. Top management must ensure that people who play a role in the implementation of the safety Management System have the right resources, competencies and guidelines to complete their tasks effectively [4][5].

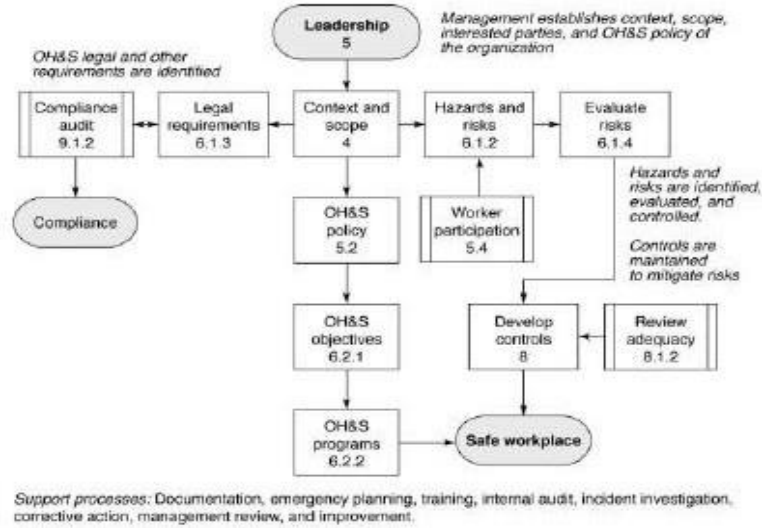

Fig. 2. Hazard and Risk management planning

\section{3) Planning}

OHS planning in ISO 45001 consists of actions in managing risks and opportunities in terms of OHS, as well as setting OHS goals and how to realize them. The organization needs to determine how to handle risks and opportunities related to OHS in each activity that takes place in the organization. This includes how to identify hazards and assess risks and opportunities related to OHS.

TABLE I. RISKS AND OPPORTUNITIES IN OCCUPATIONAL HEALTH AND SAFETY SYSTEM

\begin{tabular}{|c|c|}
\hline Opportunity category examples: & Risk category examples: \\
\hline Technology & Fatality / hospitalisation \\
\hline Training & Lost time accident \\
\hline Audits & Minor injury or accident \\
\hline Open-door policy & Slips, trips and falls \\
\hline $\begin{array}{c}\text { Staff review meetings \& Staff } \\
\text { competency quizzes }\end{array}$ & Incidents or injuries \\
\hline Training matrix & Near miss \\
\hline HR check-ups & \\
\hline Whistle-blowing tool, such as Kiosk & \\
\hline Near-miss preventive actions & \\
\hline Well being initiatives & \\
\hline Flexible working / stress management & \\
\hline
\end{tabular}

a. Source : (Qualsys, 2018a) [5]

\section{Support}

After identifying hazards, assessing risks, and determining controls, the organization needs todetermine what support is needed to implement the OHS management system. The support consists of (1) Resources; (2) competence; (3) awareness; (4) communication; and (5) information documentation.

\section{E. Operation}

The organization needs to plan, implement and control the OHS process in accordance with established procedures. The organization also needs to ensure that outsourced processes can be controlled to ensure security. In dealing with risk it is necessary to apply a control hierarchy as follows: 


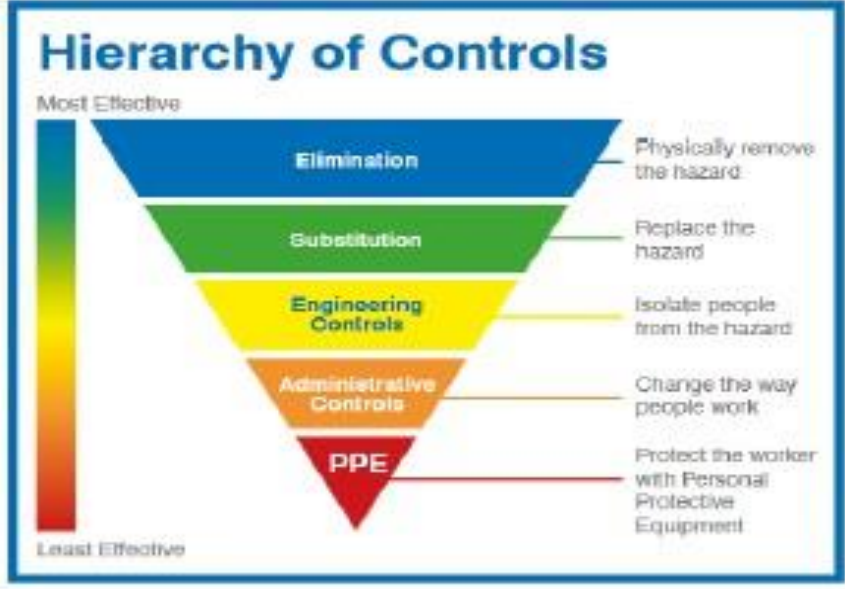

Fig. 3. Control Hierarchy, Source : (NQA, 2018) [7]

\section{1) Performance Evaluation}

Performance measurement is carried out on the safety management system to determine its effectiveness. Appropriate methods need to be considered to ensure the process of monitoring and measuring performance in accordance with the required data requirements. The data is ensured accurate, consistent, and trends can be made to see its development. Performance measurements are divided into 4 categories, namely as follows:

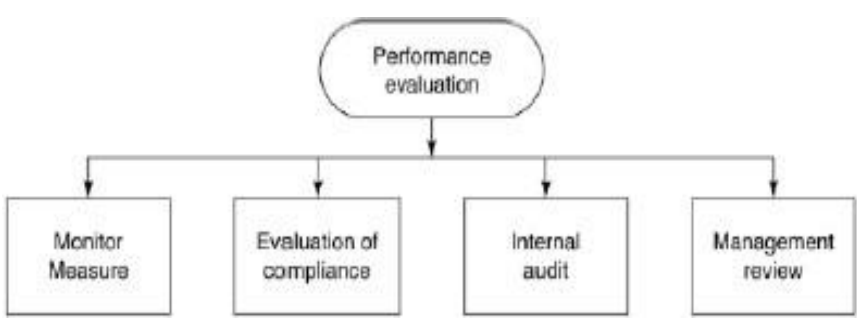

Fig. 4. Performance Evaluation, Source: (Dentch, 2018) [6]

\section{2) Improvement}

Opportunities in developing OHS System can be found through management reviews and internal audits, referring to the results of the supervision of the implementation of OHS System. Opportunities to improve OHS System performance are also obtained based on incident reports, nonconformity reports, and corrective action reports while dealing with problems that occur.

Continuous development is carried out to improve the performance of the occupational safety and health management system. Organizations need to make continuous development to improve suitability, adequacy, and effectiveness of OHS Management System. Sustainable development can be done through the following things:

- Improve OHS performance by reducing hazards and incidents, minimizing OHS risks, reducing factors that contribute to poor health such as noise, dust and smoke.

- Promoting worker participation in implementing continuous improvement programs.

- Communicating the results of continuous improvement to workers and workers' representatives.
- Maintain and store documented information about continuous improvement.

\section{METHOD}

\section{A. First Stage}

The first step is collecting the data needed to find out how the OHS Management System is applied to the research object, OHS Management System at Company X. others by conducting in the Company interviews with parties related to Company X OHS Management System. Interviews will be conducted with employees at the QSHE Bureau at Company $X$. The purpose of this interview is to know the Company $X$ OHS Management System validly and thoroughly.

TABLE II. INTERVIEW QUESTIONNAIRE

\begin{tabular}{|c|l|l|}
\hline No. & \multicolumn{1}{|c|}{ Question } & Response \\
\hline A. Safety Policy & \\
\hline 1. & $\ldots$ & \\
\hline 2. & $\ldots$ & \\
\hline \multicolumn{2}{|c|}{ B. Safety Plan } & \\
\hline 1. & $\ldots$ & \\
\hline 2. & $\ldots$ & \\
\hline
\end{tabular}

Next is the process of collecting data in the form of procedures for implementing OHS documents. The OHS System Guideline is an internal document which requires access to these documents. Therefore, because of this the author submitted permission to the Company X QSHE Bureau to be able to access the document. The list of required documents is in Appendix 1 in the following format:

TABLE III. DOCUMENT ACCESS PERMISSION REQUEST

\begin{tabular}{|c|l|c|}
\hline No. & \multicolumn{1}{|c|}{ Document } & $\begin{array}{c}\text { Document } \\
\text { Access } \\
\text { Permission }\end{array}$ \\
\hline I. General Document & \\
\hline 1. & Safety Policy Company X & \\
\hline 2. & Safety Guidelines Company X & \\
\hline 3. & $\ldots$ & \\
\hline II. Procedure Document & \\
\hline 1. & Personal Protective Equipment Procedure & \\
\hline 2. & Procedure.. & \\
\hline III. Supporting Document & \\
\hline 1. & Safety Program Company X & \\
\hline 2. & \multicolumn{2}{|c|}{} \\
\hline
\end{tabular}

\section{B. Second Stage}

The second stage is to assess the level of compliance of Company X OHS System based on Indonesia Government Regulation number 50 of 2012 and international standard ISO 45001: 2018. The study was conducted by examining the level of OHS compliance according to these points.

The first is to validate the research instruments of the experts. This is to ensure that the instrument complies with these regulations and standards and to develop the instrument if there are deficiencies. The questionnaire regarding the 
validation of the research instrument is in Appendix 2 and in the following table:

TABLE IV. RESEARCH INSTRUMENT VALIDATION

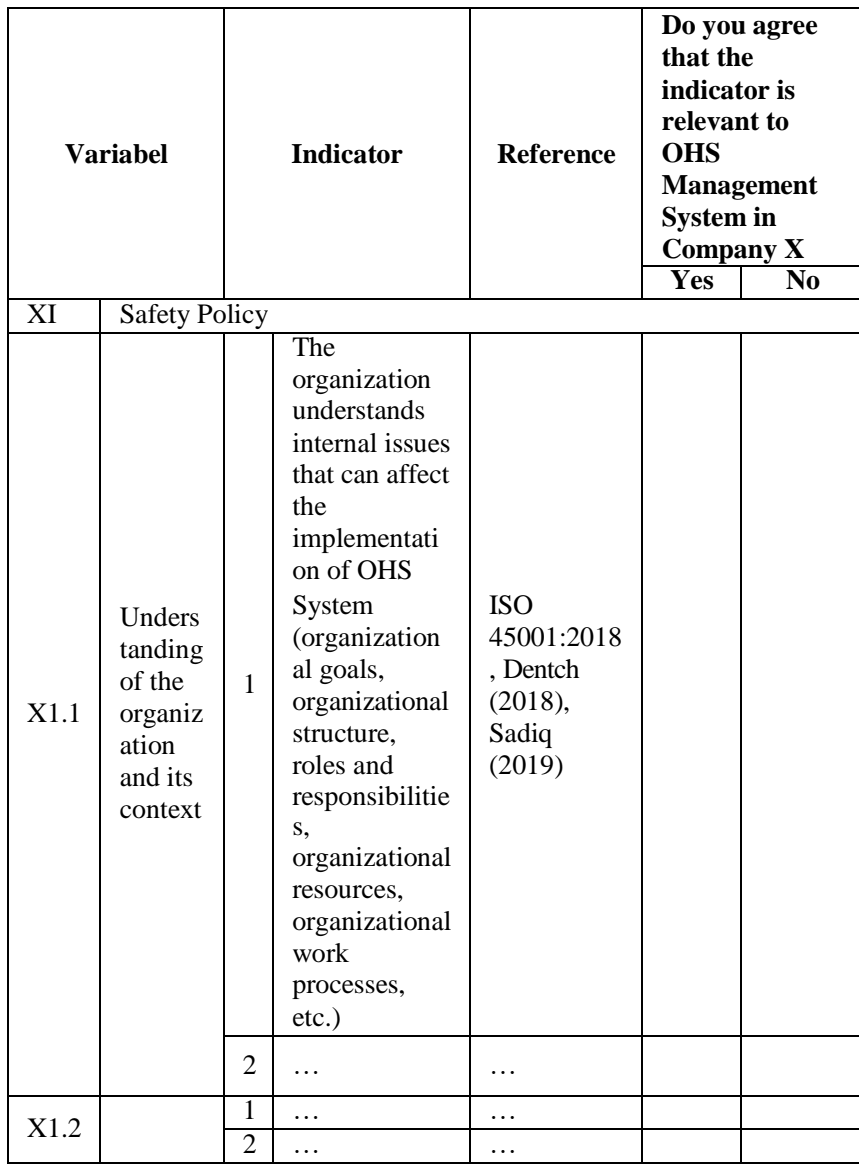

Data collection is done by compiling Company X OHS System which has been validated, then carried out an assessment (gap analysis) referring to compliance points according to the regulation. The OHS Management System compliance points based on Indonesia Government Regulation Number 50 Year 2012 attached to Appendix 3 and the following in Table 5.4 are examples:

TABLE V. RESEARCH INSTRUMENT

\begin{tabular}{|l|c|c|c|c|}
\hline No. & $\begin{array}{c}\text { Criteria for } \\
\text { Fulfilling } \\
\text { OHS }\end{array}$ & $\begin{array}{c}\text { Present } \\
\text { condition }\end{array}$ & $\begin{array}{c}\text { Relevant } \\
\text { documents }\end{array}$ & Assessment \\
\hline 1. & \multicolumn{4}{|c|}{$\begin{array}{c}\text { Safety } \\
\text { Policy }\end{array}$} \\
\hline 1.1 & Understanding of the organization and its context \\
\hline 1.1 .1 & $\ldots$ & & & \\
\hline$\ldots$ & & & & \\
\hline 1.2 & & & & \\
\hline$\ldots$ & $\ldots$ & & & \\
\hline
\end{tabular}

\section{Third Stage}

Third stage is providing recommendations and follow-up actions based on the results of the gap analysis. Data collection will be carried out by interviewing the safety Expert. Literature studies are also used as additional references in providing recommendations and follow-up. The following is an overview of the format of recommendations and follow-up to the compliance criteria that have not been met or can be developed.

TABLE VI. RECOMMENDATIONS AND FOLLOW UP

\begin{tabular}{|c|c|c|c|c|}
\hline No. & $\begin{array}{c}\text { Compliance } \\
\text { Criteria }\end{array}$ & $\begin{array}{c}\text { Present } \\
\text { Condition }\end{array}$ & $\begin{array}{c}\text { Recommendations } \\
\text { and follow up }\end{array}$ & Reference \\
\hline 1. & & & & \\
\hline$\ldots$ & & & & \\
\hline$\ldots$ & & & & \\
\hline
\end{tabular}

\section{RESEARCH VARIABLE}

The research variable is basically anything in the form of what is determined by the researcher to be studied in order to obtain information about it, then draw conclusions. The research variable is an attribute, trait or value of people, objects, or activities that have certain variations set by researchers to be studied and researched to be able to draw conclusions [8].

TABLE VII. X VARIABLE

\begin{tabular}{|c|c|c|c|}
\hline \multicolumn{2}{|r|}{ Variable } & \multicolumn{2}{|r|}{ Sub Variable } \\
\hline \multirow{4}{*}{$\mathrm{X} 1$} & \multirow{4}{*}{ Safety Policy } & $\mathrm{X} 1.1$ & Initial review of Safety \\
\hline & & $\mathrm{X} 1.2$ & Safety Policy \\
\hline & & $\mathrm{X} 1.3$ & $\begin{array}{l}\text { Job Description, Responsibility, and } \\
\text { Authority }\end{array}$ \\
\hline & & $\mathrm{X} 1.4$ & $\begin{array}{l}\text { Establish goals and objectives of the } \\
\text { OHS policy }\end{array}$ \\
\hline \multirow{5}{*}{$\mathrm{X} 2$} & \multirow{5}{*}{ Safety Plan } & $\mathrm{X} 2.1$ & $\begin{array}{l}\text { Hazard identification, project OHS } \\
\text { goals, OHS risk control, OHS } \\
\text { programs, and costs }\end{array}$ \\
\hline & & $\mathrm{X} 2.2$ & Risk management planning \\
\hline & & $\mathrm{X} 2.3$ & $\begin{array}{l}\text { Use performance indicators as an } \\
\text { evaluation of Safety performance }\end{array}$ \\
\hline & & $\mathrm{X} 2.4$ & $\begin{array}{l}\text { Compliance with laws and other } \\
\text { requirements }\end{array}$ \\
\hline & & $\mathrm{X} 2.5$ & Safety Programs \\
\hline \multirow{5}{*}{$\mathrm{X} 3$} & \multirow{5}{*}{$\begin{array}{l}\text { Safety } \\
\text { Implementation }\end{array}$} & $\mathrm{X} 3.1$ & $\begin{array}{l}\text { Trained personnel, facilities and } \\
\text { funds }\end{array}$ \\
\hline & & $\mathrm{X} 3.2$ & Operation control \\
\hline & & $\mathrm{X} 3.3$ & Document control \\
\hline & & X3.4 & Administrative control \\
\hline & & $\mathrm{X} 3.5$ & Emergency response procedure \\
\hline \multirow{3}{*}{$\mathrm{X} 4$} & \multirow{3}{*}{$\begin{array}{l}\text { Monitoring and } \\
\text { Evaluation }\end{array}$} & $\mathrm{X} 4.1$ & $\begin{array}{l}\text { Monitor, measure and evaluate } \\
\text { performance }\end{array}$ \\
\hline & & $\mathrm{X} 4.2$ & Internal Audit \\
\hline & & $\mathrm{X} 4.3$ & Corrective action \\
\hline \multirow{2}{*}{$\mathrm{X} 5$} & \multirow{2}{*}{$\begin{array}{l}\text { Safety } \\
\text { Performance } \\
\text { Review and } \\
\text { Improvement }\end{array}$} & X5.1 & Re-discuss evaluation / inspection \\
\hline & & X5.2 & $\begin{array}{l}\text { Evaluate the effectiveness of The } \\
\text { Implementation OHS System }\end{array}$ \\
\hline
\end{tabular}


TABLE VIII. Y VARIABLE

\begin{tabular}{|c|c|c|c|c|c|}
\hline \multicolumn{2}{|c|}{ Variable } & \multicolumn{2}{|c|}{ Sub Variable } & \multicolumn{2}{|r|}{ Indicator } \\
\hline \multirow{14}{*}{ Y1 } & \multirow{14}{*}{$\begin{array}{c}\text { OHS } \\
\text { Management } \\
\text { System } \\
\text { Company X }\end{array}$} & \multirow[b]{2}{*}{ Y1.1 } & \multirow[b]{2}{*}{$\begin{array}{l}\text { Commitment } \\
\text { and Policy }\end{array}$} & 1 & $\begin{array}{l}\text { Leadership } \\
\text { and } \\
\text { Commitment }\end{array}$ \\
\hline & & & & 2 & $\begin{array}{l}\text { Occupational } \\
\text { Safety, } \\
\text { Health and } \\
\text { Environment } \\
\text { Policy }\end{array}$ \\
\hline & & \multirow{3}{*}{ Y1.2 } & \multirow{3}{*}{ Planning } & 1 & $\begin{array}{l}\text { Hazard } \\
\text { Identification, } \\
\text { Assessment } \\
\text { and Control } \\
\text { of HSE Risk }\end{array}$ \\
\hline & & & & 2 & $\begin{array}{l}\text { Legislation } \\
\text { and Other } \\
\text { Requirements }\end{array}$ \\
\hline & & & & 3 & $\begin{array}{l}\text { Purpose and } \\
\text { Target }\end{array}$ \\
\hline & & \multirow{4}{*}{ Y1.3 } & \multirow{4}{*}{ Implementation } & 1 & $\begin{array}{l}\text { Human } \\
\text { Resources, } \\
\text { Facilities, } \\
\text { Funds } \\
\end{array}$ \\
\hline & & & & 2 & $\begin{array}{l}\text { Supporting } \\
\text { Activities }\end{array}$ \\
\hline & & & & 3 & $\begin{array}{l}\text { Operational } \\
\text { Control }\end{array}$ \\
\hline & & & & 4 & $\begin{array}{l}\text { Emergency or } \\
\text { Disaster }\end{array}$ \\
\hline & & \multirow[b]{3}{*}{ Y1.4 } & \multirow[b]{3}{*}{$\begin{array}{l}\text { Measurement } \\
\text { and Evaluation }\end{array}$} & 1 & $\begin{array}{l}\text { Performance } \\
\text { Monitoring } \\
\text { and } \\
\text { Measurement }\end{array}$ \\
\hline & & & & 2 & $\begin{array}{l}\text { Conformity } \\
\text { Evaluation }\end{array}$ \\
\hline & & & & 3 & $\begin{array}{l}\text { Investigation } \\
\text { of Incidents, } \\
\text { Non- } \\
\text { compliance, } \\
\text { Corrective } \\
\text { Actions and } \\
\text { Preventive } \\
\text { Measures }\end{array}$ \\
\hline & & \multirow[b]{2}{*}{ Y1.5 } & \multirow{2}{*}{$\begin{array}{l}\text { Review and } \\
\text { Improvement }\end{array}$} & 4 & Internal Audit \\
\hline & & & & 1 & $\begin{array}{l}\text { Review and } \\
\text { Improvement }\end{array}$ \\
\hline
\end{tabular}

b. Source: Aditya Nugroho, 2019

\section{DATA ANALYSIS}

\section{A. First Stage}

The first stage is the stage to identify and validate Company OHS System. The analysis is done by describing the results of the interview and outlining the contents of Company X OHS System documents that can be obtained during the study.

\section{B. Second Stage}

The second stage is the assessment of Company X OHS System compliance level based on Government Regulation number 50 of 2012 and international standard ISO 45001: 2018. The analysis is carried out as in Table 3.4, namely by presenting the current conditions, writing relevant documents and evidence of work or activities, and filling out an assessment based on both of them. The rating scale is determined based on the scientific journal Yahya (2018) on OHS System evaluation referring to ISO 45001: 2018 namely as in the following Table 5.1. The evaluation scale has also been validated by experts to get recommendations or improvements related to the rating scale.

\begin{tabular}{|c|c|}
\multicolumn{2}{l}{ TABLE IX. $\quad$ SCORING SCALE } \\
\hline Scoring & \multicolumn{1}{c|}{ information } \\
\hline 0 & $\begin{array}{l}\text { There are no procedures yet and } \\
\text { have not been implemented }\end{array}$ \\
\hline 1 & $\begin{array}{l}\text { There are procedures that have not been } \\
\text { implemented, or have been carried out } \\
\text { but without procedures }\end{array}$ \\
\hline 2 & $\begin{array}{l}\text { There are procedures and have been } \\
\text { implemented but are less consistent }\end{array}$ \\
\hline 3 & $\begin{array}{l}\text { There are procedures and have } \\
\text { been implemented } \\
\text { consistently }\end{array}$ \\
\hline
\end{tabular}

c. Aditya Nugroho, 2019

Data obtained through this assessment is ordinal type data, then the percentage of compliance level measurements are taken as follows. This percentage of compliance level aims to provide a general description of the implementation of OHS System at Company X. The following is the formula used to calculate the percentage of compliance:

\section{Percentage of Compliance $=\mathrm{a} / \mathrm{b} \times 100 \%$ \\ Information:}

$$
\begin{aligned}
& \mathrm{a}=\text { Completion Rate Points Obtained } \\
& \mathrm{b}=\text { Total Compliance Points }
\end{aligned}
$$

\section{Third Stage}

\section{Third Stage}

The third stage is giving recommendations and followup based on the results of the level of Company X OHS Management System compliance. Recommendations and follow-up are given through the results of interviews by Safety experts and literature studies. The purpose of this stage is to obtain recommendations and follow up that can be applied so that the OHS management system can meet the regulatory requirements and standards used, as well as a means to carry out continuous development in designing the OHS management system.

\section{CONCLUSION AND LIMITATION}

The conclusion of this study is to conduct an evaluation or assessment of the level of compliance with the safety and health management system at Company X. This study uses regulations and OHS standards as the basis of the level of OHS compliance. The regulation used is Indonesia Government Regulation Number 50 of 2012 concerning the application of occupational safety and health management systems. The standard used is ISO 45001: 2018 about Occupational Health \& Safety.

This research was conducted at Company X. Data collection was carried out by interviewing parties related to the Safety field at Company X, namely the QSHE (Quality Safety Health and Environment) Bureau. The assessment is 
carried out using the Gap analysis Method by examining Company X OHS System elements one by one and comparing them with the OHS elements according to regulations and applicable standards.

This research still very limited related to expert validation, numbers of expert needed to test the validity of performance indicator. This research still can be developed until case study to evaluate implementation of OHS Management System at Company X has been validated.

\section{ACKNOWLEDGMENT}

The preferred spelling of the word "acknowledgment" in America is without an "e" after the "g". Avoid the stilted expression "one of us (R. B. G.) thanks ...". Instead, try "R. B. G. thanks...". Put sponsor acknowledgments in the unnumbered footnote on the first page.

\section{REFERENCES}

[1] Website PT Wijaya Karya Bangunan Gedung Tbk, Keselamatan, Kesehatan Kerja \& Lingkungan. https://www.wikagedung.co.id/dev/keberlanjutan/keselamatan kese hatan_kerja lingkungan.html

[2] RoI 2012 Peraturan Pemerintah Republik Indonesia No. 50 Tahun 2012 tentang Penerapan Sistem Manajemen Keselamatan dan Kesehatan Kerja [Regulation from Indonesia Governemt Number 50 of 2012 Concerning Occupational Health and Safety Management System] (Jakarta : Republic of Indonesia).

[3] Organisation Internationale de Normalisation (ISO), (2018), "Occupational Health \& Safety ISO 45001:2018”, (https://www.iso.org)

[4] Cadwell, C. 2016. ISO 45001:2018 a short and simple guide. Newground.

[5] Qualsys. 2018a. ISO 45001:2018 risks and opportunities. https://quality.eqms.co.uk/blog/iso-450012018-risks-andopportunities-tips-examples-and-ideas diakses 21 Desember 2019

[6] Dentch, M. P. 2018. The ISO 45001:2018 implementation handbook. American Society for Quality.

[7] NQA. 2018. ISO 45001:2018 Implementation Guide. National Quality Assurance.

[8] Sugiyono 2006 Metode Penelitian Kuantitatif, Kualitatif dan R \& D.[Sugiyono- Quantitative, Qualitative, and R\&D Research Methods] (Bandung:Alfabeta 